\title{
Pelatihan Pembuatan Produk Ekonomi Kreatif Kriya Tekstil dengan Teknik Shibori kepada Ibu-ibu Dawis Cempaka
}

Workshop on Making Creative Economy Products of Textile Craft with Shibori Technique for Dawis Cempaka

\author{
Amalia $^{1}$, Dwi Nurul Izzhati ${ }^{2}$, Dita Ayu Mayasari ${ }^{3}$ \\ 1,2Teknik Industri, Fakultas Teknik, Universitas Dian Nuswantoro \\ ${ }^{3}$ Teknik Biomedis, Fakultas Teknik, Universitas Dian Nuswantoro \\ E-mail: 1amalia@dsn.dinus.ac.id, ${ }^{2}$ penulis.2@email.ac.id, ${ }^{3}$ mayasari.dita@dsn.dinus.ac.id
}

\begin{abstract}
Abstrak
Pengembangan ekonomi kreatif menjadi salah satu pilar perekonomian nasional yang potensial. Salah satu produk unggulan pada subsektor ekonomi kreatif di Indonesia adalah kriya, khususnya kriya tekstil. Produk kreatif kriya tekstil yang saat ini sedang diminati masyarakat, serta memiliki nilai jual dan estetika tinggi adalah teknik celup ikat Shibori. Sasaran kegiatan pengabdian masyarakat adalah Ibu-ibu Kelompok Dawis Cempaka. Tujuan pengabdian adalah untuk meningkatkan pengetahuan, dan keterampilan dalam membuat produk kreatif, serta meningkatkan motivasi warga untuk berproduksi dan berwirausaha. Keberhasilan pelatihan ditandai dengan: a. peningkatan pengetahuan yaitu mampu menjawab benar soal $(94 \%)$; b. kepuasan terhadap kegiatan pelatihan (97\%); dan c. minat membuka usaha (92\%).
\end{abstract}

Kata kunci: ekonomi kreatif, celup ikat, Shibori, pelatihan

\section{Abstract}

Creative economy is one of the potential pillars of the national economy. While the one of the leading products in the subsector of creative economy in Indonesia is craft, especially textile craft. The creative textile products that are currently in demand, along has high selling and aesthetic value is Shibori tie dyeing technique. The target of community service activity is the women of Dawis Cempaka in Semarang. The purpose is to increase knowledge and skills in making creative products, as well as increase the motivation of citizens to produce it and be entrepreneurs. The success of the workshop is marked by: a. increasing knowledge that is able to answer the correct questions $(94 \%)$; b. satisfaction with the workshop (97\%); and c. interest to start up business (92\%).

Keywords: creative economy, tie dye, Shibori, workshop

\section{PENDAHULUAN}

Pengembangan ekonomi kreatif di Indonesia mendapat perhatian besar dari para pelaku usaha dan pemerintah, dikarenakan memiliki potensi dalam memberikan nilai tambah, maupun lapangan pekerjaan. Menurut Firdausy [1], meskipun sektor ekonomi kreatif memiliki peranan penting terhadap perekonomian nasional, masih terdapat beberapa permasalahan, antara lain: (1) tataran regulasi dan infrastruktur penunjang belum menyadari potensi dari keberadaan ekonomi kreatif; (2) pemerintah daerah belum mampu menstimulasi wujud kreatif masyarakat. Dalam buku Ekonomi Kreatif - Pilar Pembangunan Indonesia [4] disampaikan bahwa negara-negara maju menyadari bahwa mereka harus lebih mengandalkan sumber daya manusia yang kreatif sebagai sumber ekonomi di negaranya. Pada era ekonomi kreatif, pemanfaatan kreatifitas dan 
penciptaan inovasi menjadi salah satu faktor daya saing.

Indonesia merupakan negara yang unggul dalam menghasilkan kerajinan kriya. Kriya yang akan diterapkan pada pengabdian ini mengarah pada kriya tekstil. Salah satu produk kriya tekstil yang menjadi pembahasan yaitu Shibori. Shibori merupakan teknik kerajinan konvensional dalam pencelupan kain yang berasal dari Jepang. Shibori juga dikenal di Indonesia dengan istilah jumputan, meski secara teknik masih dilakukan dengan cara-cara yang cukup sederhana [5].

Maharani dan Martono mempublikasikan karya kriya tekstil dengan teknik arashi shibori untuk scarf dengan kain sutera dan memiliki nilai estetik [6]. Teknik Shibori memberikan variasi dan inovasi baru dalam produk, terlebih lagi teknik Shibori memiliki beberapa teknik. Teknik dasar shibori yaitu arashi shibori, kumo shibori, dan itajime shibori [3]. Perkembangan teknik Shibori juga memasuki industri fesyen di Indonesia, dengan peminat yang banyak.

Inisiasi masyarakat untuk menjadi pelaku usaha dalam bidang ekonomi kreatif masih perlu disosialisasikan dan didukung. Untuk menjadi pelaku usaha kreatif maka perlu dikembangkan baik dari pengetahuan maupun keterampilan untuk bisa menjadi sumber daya manusia (SDM) yang kompeten, mampu menciptakan produk kreatif dan inovatif. Perlunya peran pemerintah, akademisi, dan bisnis secara maksimal sebagai wujud implementasi triple helix dalam mendorong pertumbuhan industri kreatif [2].

Ibu-ibu Dawis Cempaka berlokasi di wilayah sangat strategis, karena dilintasi jalur utama pantai utara (pantura) yang menjadi urat nadi perekonomian Jawa. Pada wilayah ini fasilitas yang tersedia juga relatif berkembang, dimana terdapat kawasan Industri Candi sebagai area kegiatan bisnis. Ibu-ibu Dawis Cempaka rata-rata memiliki usia produktif, dan berperan sebagai ibu rumah tangga. Berdasarkan permasalahan tersebut, diharapkan dengan adanya pelatihan kriya tekstil teknik shibori nantinya akan dapat meningkatkan keterampilan warga dalam membuat produkproduk kreatif, meningkatkan motivasi warga untuk berproduksi dan berwirausaha sebagai upaya kemandirian dalam perekonomian keluarga

\section{METODE PELAKSANAAN}

Pelaksanaan kegiatan pelatihan pembuatan produk ekonomi kreatif kriya tekstil dengan teknik Shibori meliputi empat tahapan utama, yaitu 1) Studi Awal; 2) Persiapan Teknis; 3) Pelaksanaan; dan 4) Evaluasi, yang dapat dilihat pada Gambar 1.
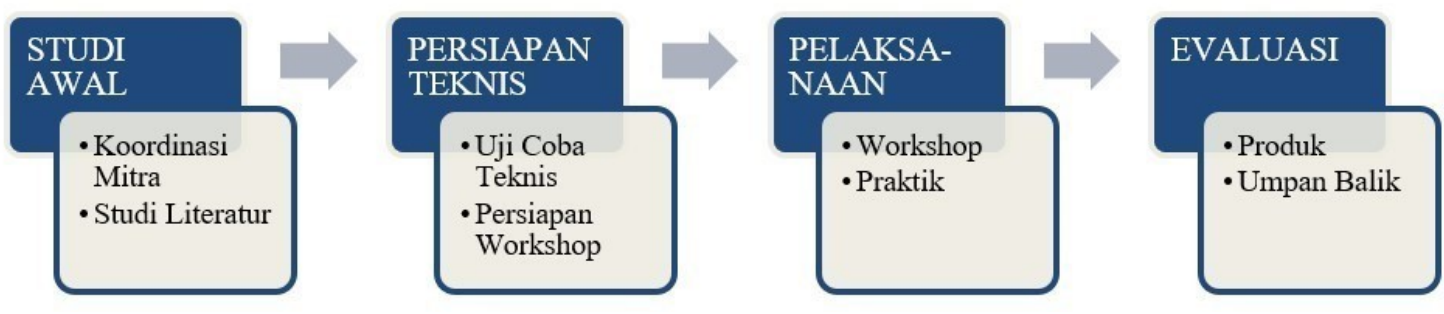

Gambar 1. Tahapan Kegiatan Pengabdian Masyarakat

\subsection{Studi Awal}

Tahapan ini merupakan tahapan awal dari pelaksanaan kegiatan pengabdian, yaitu:

\section{Koordinasi Mitra}

Mitra adalah Kelompok Dawis Cempaka, Kelurahan Purwoyoso, Kecamatan Ngaliyan, Kota Semarang. Koordinasi ditujukan untuk: a) menganalisis situasi mitra; b) menentukan kebutuhan akan pelatihan; c) menentukan teknis pelaksanaan pengabdian

2. Studi Literatur

Studi literatur dilakukan untuk mendalami secara teoritis maupun praktik pelatihan, dan sebagai acuan yang akan digunakan dalam menyusun laporan dan modul pelatihan. 


\subsection{Persiapan Teknis}

Persiapan teknis dari pelatihan ini terdiri dari:

1. Uji Coba Teknis

Uji coba teknis meliputi kegiatan pembuatan produk dengan Teknik Shibori yang akan dijadikan contoh produk dan tutorial pembuatan produk. Uji coba teknis yang digunakan menggunakan dengan 2 jenis bahan kain, dengan 3 teknik utama Shibori, yaitu Itajime, Kumo, dan Arashi. Contoh sampel yang dibuat sebanyak 17 produk.

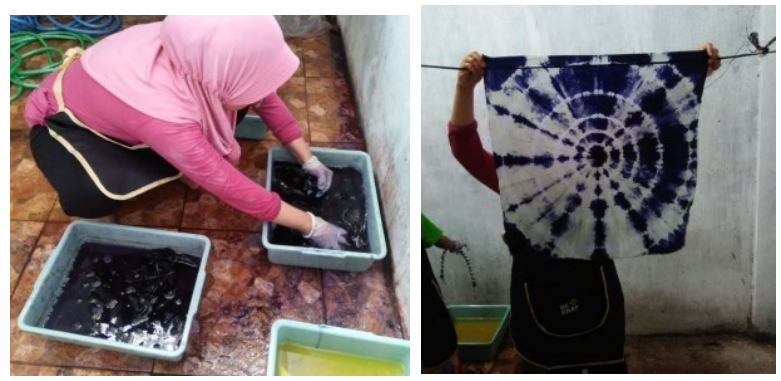

Gambar 2. Uji Coba Teknis

2. Persiapan Kebutuhan Pelatihan

Persiapan kebutuhan pelaksanaan pelatihan, meliputi:

a. Persiapan peralatan

Peralatan yang dibutuhkan antara lain (a) ember celup, (b) variasi untuk penjepit itajime, (c) karet dan rafia untuk pengikat kumo; (d) pengisi seperti manik-manik, koin, kelereng, dll; (d) peralon untuk teknik arashi.

b. Persiapan bahan

Bahan yang diperlukan adalah (a) kain selendang berbahan rayon viscosa dengan ukuran 160 x $40 \mathrm{~cm}$, (b) pewarna Naphtol dan garam Naphtol, (c) kaustik soda

c. Pembuatan modul pelatihan

Modul pelatihan berisi materi mengenai ekonomi kreatif dan shibori. Pada bahan ekonomi kreatif dijelaskan mengenai literatur definisi dan sektor-sektor yang menjadi unggulan dan prioritas. Materi mengenai Shibori mengenai teknik-teknik ikatan, bahan-bahan yang diperlukan dan gambaran mengenai produk yang dihasilkan. Modul pelatihan terdiri dari 28 halaman.

\subsection{Pelaksanaan Kegiatan}

Pada tahap ini, tim membuat susunan acara pelaksanaan kegiatan pengabdian, yang terdiri dari: a) Sambutan; b) Penilaian pengetahuan awal peserta; c) Pemberian materi terkait ekonomi kreatif; d) Pemberian materi terkait Shibori; e) Tutorial teknik ikatan; f) Praktik pembuatan produk; g) Sesi Foto Produk; h) Penilaian pengetahuan akhir peserta; i) Umpan balik dari peserta; dan j) penutup. Penilaian pengetahuan awal digunakan untuk mengetahui pemahaman awal peserta terhadap materi yang akan disampaikan. Pelatihan yang diberikan meliputi 3 teknik ikatan Shibori. Sesi foto produk dilakukan sebanyak dua (2) kali, yaitu produk yang sudah diikat tanpa pewarnaan; dan produk yang sudah dilakukan pewarnaan. Penilaian pengetahuan akhir juga dilakukan guna mengetahui seberapa baik pengetahuan yang diterima oleh peserta. Umpan balik juga dilakukan guna mengetahui tanggapan peserta terhadap kegiatan dan masukan agar pelatihan dapat menjadi lebih baik di kemudian hari.

\subsection{Evaluasi evaluasi \\ Pada tahapan evaluasi dilakukan penyusunan laporan pertanggungjawaban kegiatan dan kegiatan pelatihan}




\section{HASIL DAN PEMBAHASAN}

Kegiatan pelatihan dilaksanakan kepada Ibu-ibu kelompok Dawis Cempaka Kelurahan Purwoyoso, Semarang pada tanggal 26 Januari 2020 di Rumah Ibu Ketua Dawis di Srikaton Barat.

\subsection{Praktik Pembuatan Produk dengan Teknik Shibori}

Pada praktik pembuatan, teknik yang diajarkan ada 3, yaitu teknik itajime, kumo, dan arashi. Selain ketiga teknik utama yang diajarkan, peserta pelatihan dapat mengkombinasikan teknik-teknik tersebut, sehingga menjadikan produk menjadi lebih beragam. Peserta juga dapat mengeluarkan ide dan kreatifitas dalam pembuatan ikatan.

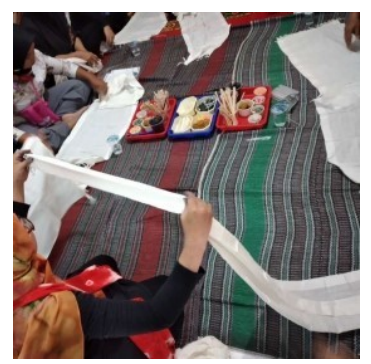

(a)

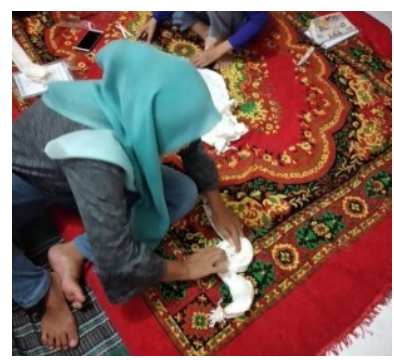

(b)

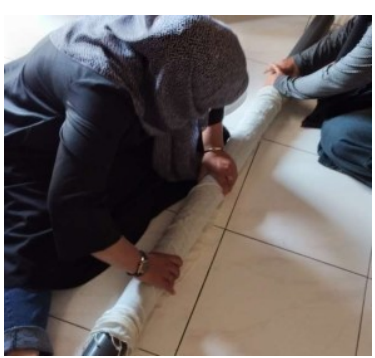

(c)

Gambar 3. Praktik pembuatan ikatan Shibori (a) Itajime; (b) Kumo; dan (c) Arashi

Setelah kain diikat, maka tahap selanjutnya peserta akan melakukan pewarnaan. Pewarnaan yang digunakan pada pelatihan ini dengan teknik celup menggunakan pewarna Naphtol AS dengan garam Naphtol Merah R, yang menghasilkan warna merah cerah.

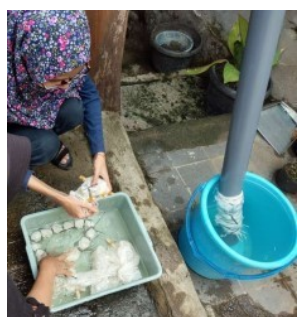

(a)

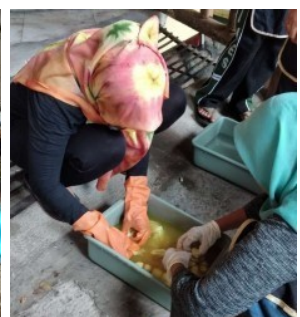

(b)

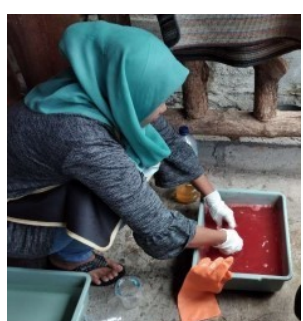

(c)

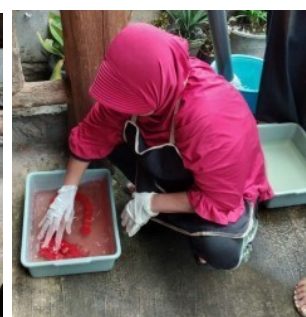

(d)

Gambar 4. Proses pewarnaan

\subsection{Hasil Produk Kreatif dengan Teknik Shibori}

Setelah pewarnaan selesai, maka ikatan Shibori dapat dibuka, dan produk dapat langsung dilihat hasilnya. Hasil ikatan Shibori akan memberikan pola indah pada kain. Kain yang kemudian dapat dijemur dan digunakan sebagai produk selendang yang memiliki nilai estetika dan nilai jual. Teknik ikatan itajime arashi akan membentuk pola lipatan yang berulang, sedangkan teknik kumo akan membentuk pola ikatan, serta teknik arashi akan membentuk seperti badai.

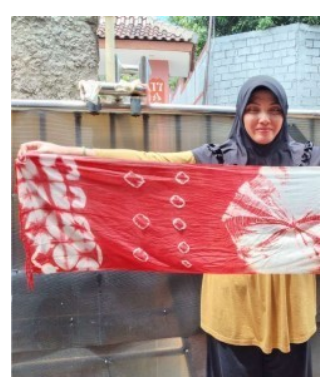

(a)

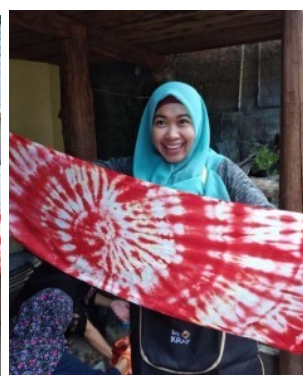

(b)

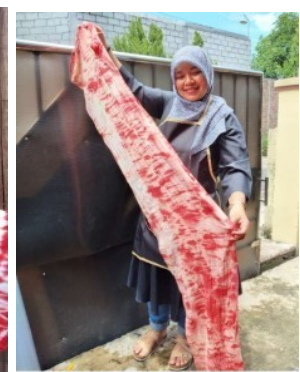

(c)

Gambar 5. Produk dengan teknik Shibori: (a) kombinasi itajime dan kumo; (b) kumo pelangi; (c) arashi 


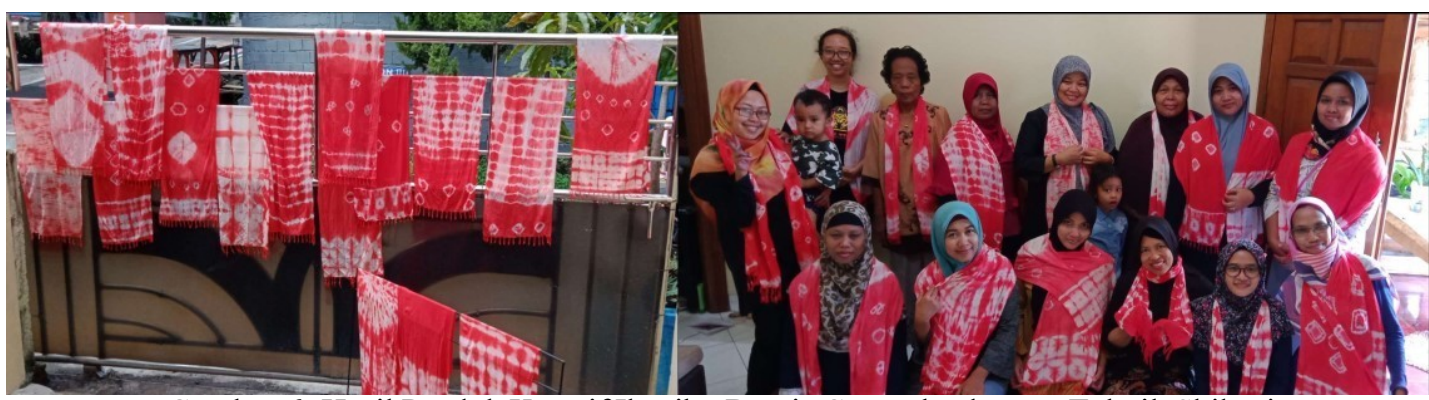

Gambar 6. Hasil Produk Kreatif Ibu-ibu Dawis Cempaka dengan Teknik Shibori

Pelatihan yang diberikan menambah wawasan dan keterampilan peserta untuk membuat produk selendang dengan berbagai teknik Shibori. Untuk menghasilkan produk yang lebih bervariasi, membutuhkan kreativitas dari masing-masing peserta dalam membuat ikatan. Berbagai teknik ikatan lainnya akan menghasilkan motif yang lebih beragam.

\subsection{Penilaian Pengetahuan dan Minat Peserta}

Pada penilaian awal digunakan untuk mengetahui pemahaman mengenai ekonomi kreatif dan Shibori. Hasil penilaian menunjukkan bahwa beberapa peserta belum mengetahui tentang ekonomi kreatif (23\%), pernah mendengar tetapi belum paham (46\%), sudah mengetahui dan paham (31\%). Hasil penilaian juga menunjukkan bahwa mayoritas peserta tidak mengetahui mengenai teknik shibori (46\%), sudah pernah mendengar tetapi belum memahami (38\%), dan hanya sedikit yang sudah mengetahui mengenai shibori (15\%).

Setelah mendapatkan pelatihan dan penjelasan, selanjutnya pengetahuan diperiksa dengan menjawab empat soal pertanyaan, dimana hasilnya menunjukkan bahwa, semua peserta mampu menjawab dengan benar mengenai ekonomi kreatif, sedangkan pada pertanyaan mengenai teknik Shibori pada no. 3 sebanyak 92,31\% menjawab benar, dan pada no.4 sebanyak $84,62 \%$. Secara keseluruhan, dapat digambarkan perubahan grafik pengetahuan terhadap ekonomi kreatif dan shibori dapat dilihat pada Gambar 7 di bawah ini.

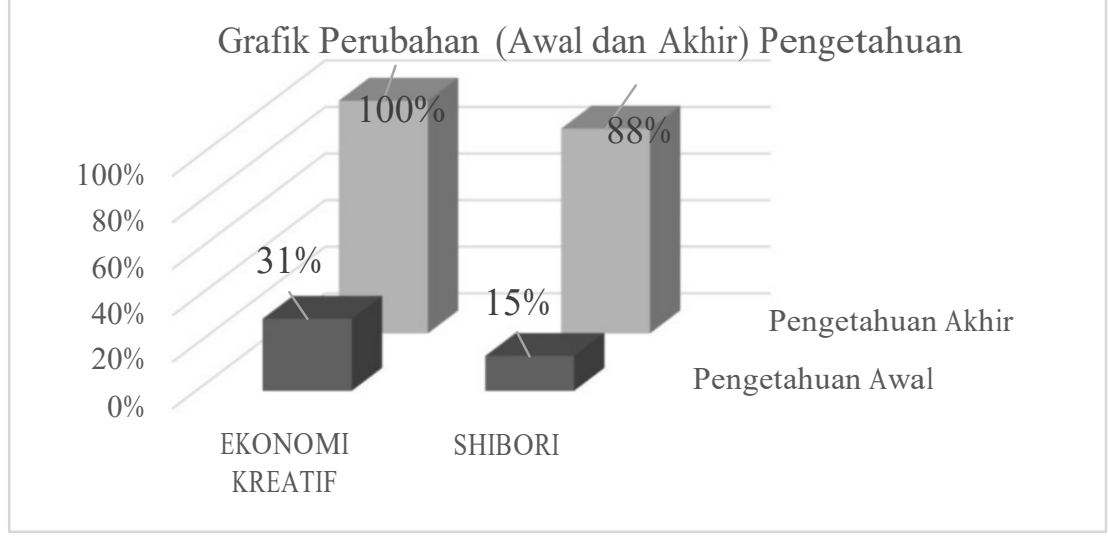

Gambar 7. Gambaran peningkatan pengetahuan

Pemberian pelatihan ini tidak hanya meningkatkan pengetahuan dan keterampilan, tetapi harapannya juga untuk menumbuhkan semangat berwirausaha dalam bidang ekonomi kreatif, khususnya

untuk 


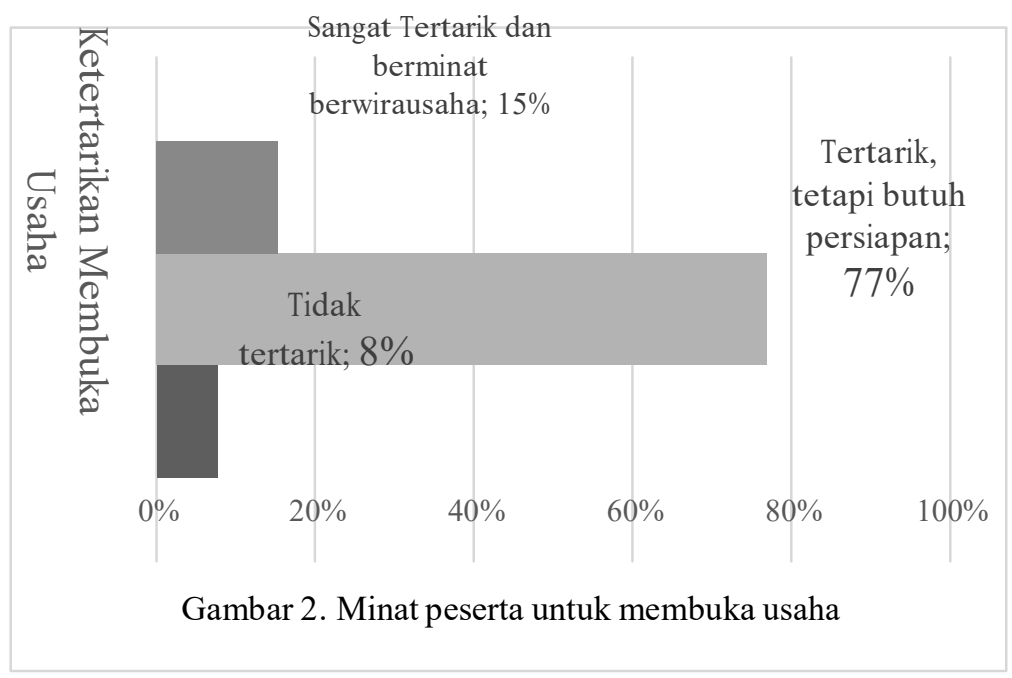

\subsection{Umpan Balik Pelatihan}

Pada awal pelatihan, peserta diminta untuk memberikan gambaran ketertarikan terhadap pelatihan yang akan diberikan. Hasilnya adalah semua peserta $(100 \%)$ menunjukkan rasa penasaran, senang, dan tertarik untuk mengikuti pelatihan. Kemudian, setelah diberikan pelatihan, peserta latih diminta untuk memberikan tanggapan kepuasan terhadap pelatihan yang diikuti, meliputi perasaan menyukai /senang terhadap kegiatan pelatihan, kelengkapan fasilitas dalam pelatihan, dan minat untuk mengikuti pelatihan Shibori yang lebih mendalam.

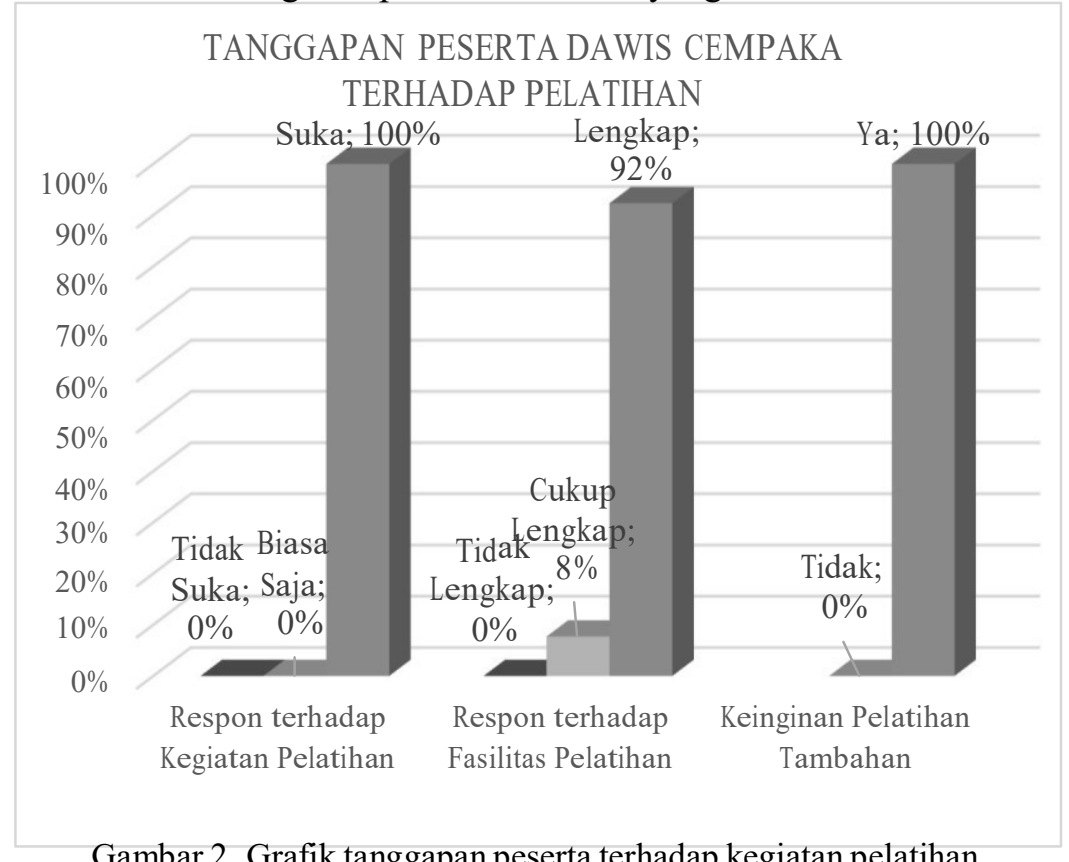

Berdasarkan hasil kuesioner umpan balik, kepuasan terhadap pelatihan mencapai 97\%, dimana $100 \%$ peserta menyukai kegiatan pelatihan, $97 \%$ peserta juga merasa bahwa fasilitas pelatihan yang diberikan sudah lengkap, dan $100 \%$ peserta menginginkan pelatihan Shibori tingkat lanjut. Peserta juga menginginkan kegiatan pelatihan dapat dilanjutkan, sehingga dapat bereksplorasi dan keterampilan lebih meningkat dalam menghasilkan karya yang lebih banyak 
dan berkualitas. Peserta juga mengharapkan pelatihan untuk berbagai jenis warna yang berbeda. Ada pula masukan untuk memberikan gambaran yang lebih terperinci untuk memulai usaha.

\section{KESIMPULAN DAN SARAN}

Kesimpulan yang diperoleh adalah kegiatan pelatihan dapat menambah pengetahuan, keterampilan, dan minat berwirausaha bagi Ibu-ibu Kelompok Dawis Cempaka. Peserta mampu menjawab soal dengan benar sebanyak 94\%. Setiap peserta mampu membuat produk menunjukkan keterampilan mulai berkembang, keterampilan akan meningkat apabila setelah pelatihan dilakukan pendampingan dan terus berlatih secara mandiri. Sebanyak 15\% peserta siap untuk membuka usaha, dan $77 \%$ tertarik membuka usaha tetapi masih membutuhkan persiapan.

Saran dalam kegiatan ini adalah pengabdian dapat dilakukan secara berkelanjutan untuk teknik-teknik Shibori yang lain, teknik pewarnaan juga dapat dilakukan dengan variasi yang lebih banyak, serta media dapat menggunakan jenis kain yang berbeda, serta produk yang dibuat juga lebih beragam. Adanya pendampingan akan meningkatkan minat dan kesiapan peserta untuk mewujudkan usaha baru dengan menggunakan teknik yang telah dilatihkan.

\section{UCAPAN TERIMA KASIH}

Terimakasih kami ucapkan kepada Lembaga Penelitian dan Pengabdian kepada Masyarakat (LPPM) Universitas Dian Nuswantoro yang telah memberikan fasilitas dan dukungan dalam pelaksanaan pengabdian masyarakat. Ucapan terimakasih juga kepada mitra, dan beberapa pihak lain yang tidak dapat kami sebutkan satu per satu.

\section{DAFTAR PUSTAKA}

[1] Firdausy, Carunia Mulya, 2017, Strategi Pengembangan Ekonomi Kreatif di Indonesia, Jakarta: Yayasan Pustaka Obor Indonesia.

[2] Izzati, Muhammad Fakhrul, dan Wilopo, 2018, Implementasi Triple Helix dalam Mendorong Pertumbuhan Industri Kreatif di Kota Malang sebagai Upaya Peningkatan Daya Saing untuk Menghadapi Masyarakat Ekonomi ASEAN, Jurnal Administrast Bisnis (JAB), Vol. 55 No. 1 Februari 2018

[3] Kautsar, Dinda Siti, 2017, Eksplorasi Teknik Shibori pada Pakaian Ready to Wear, eproceeding of Art \& Design,Vol. 4, No. 3 Desember 2017, ISSN: 2355-9349.

[4] Purnomo, Rochmat Aldy, 2016, Ekonomi Kreatif: Pilar Pembangunan Indonesia, Surakarta: Ziyad Visi Media.

[5] Suantara, Dermawati, Endah Oktaviano, dan Yusniar Siregar, 2018, Eksplorasi Teknik Shibori dalam Pengembangan Desain Motif Tradisional Indonesia pada Permukaan Kain Sandang, Arena Tekstil, Vol. 32 No. 2, 2017:67-76.

[6] Maharani, Riesyanita dan John Martono, Jurnal Tingkat Sarjana Seni Rupa dan Desain, No. 1.

[7] Fintinline, 2018, 6 Teknik Dasar Shbori yang Mudah untuk Anda Ikuti, https://fitinline.com/article/read/6-teknik-dasar-shibori-yang-mudah-untuk-anda-ikuti/ diakses pada tanggal 16 Oktober 2019.

[8] Lovenia, H, 2016, Studium Generale: Rebut Pasar Dunia Berbekal Ekonomi Kreatif https://www.itb.ac.id/news/read/5283/home/studium-generale-rebut-pasar-dunia-berbekalekonomi-kreatif diakses pada tanggal 16 Oktober 2019. 